\title{
EVALUATION OF PROBABILITY OF BRIDGE DAMAGE AS A RESULT OF TERRORIST ATTACK
}

\author{
A. DUCHACZEK ${ }^{1}$, D. SKORUPKA ${ }^{2}$
}

\begin{abstract}
The paper presents an approach for evaluation of the likelihood of damage to the transportation infrastructure in the context of the terrorist attacks on the example of a number of bridges located in Wrocław (Poland). Assuming that there will be only one bridge destroyed in a given area, in order to determine the probability of damage to one of the objects, there was one of multi-criteria optimization methods used, i.e. the method of Analytical Hierarchy Process (AHP). The main advantage of the analysis carried out was that the accepted hierarchy of decision-making options could be easily explained in a scientific manner, not only with reference to personal knowledge, experience, and intuition.
\end{abstract}

Key words: AHP method, crisis management, risk evaluation

\section{INTRODUCTION}

According to the Act of 26 April 2007 on crisis management [1], the critical infrastructure includes transportation system and their constituent functionally interrelated objects, such as buildings, equipment, facilities, services essential for the safety of the state and its citizens, and for ensuring the effective functioning of the public administration, as well as institutions and enterprises.

Critical infrastructure includes, among others, transportation system [1], which according to D. Pyza [2] is responsible for the movement of goods (materials and products) between the fixed network elements and logistics systems, such as, e.g. manufacturing facilities, warehouses and shops.

One of the elements of the transportation system is its infrastructure, which consists of mainly three major groups, i.e. all modes of transport routes, points of transportation (airports, ports, etc.) and ancillary equipment used to directly control the roads and transport points [3]. An essential element of the road, for both cars and railways, are always bridges, which include various types of bridges, overpasses, underpasses, and

1 Management Department, General Tadeusz Kosciuszko Military Academy of Land Forces, Czajkowskiego Street 109, 51-150 Wroclaw, Poland, e-mail: aduchaczek@poczta.wp.pl

2 Management Department, General Tadeusz Kosciuszko Military Academy of Land Forces, Czajkowskiego Street 109, 51-150 Wroclaw, Poland, e-mail: dareks100@interia.eu 
culverts. It is the safe operation of these facilities that the authors want to devote their attention to in the presented paper.

In light of the Act [1], protection of critical infrastructure includes all measures imposed to ensure the functionality, continuity and integrity of critical infrastructure in order to prevent threats, risks, weaknesses or limitations, and neutralizing their effects, as well as their rapid restoration in the case of emergencies, attacks, and other events that may interfere with its proper functioning. In the Act [1] under consideration, there is a risk map concept defined as a map or description showing the potentially negative effects of hazards on people, environment, property and infrastructure.

The crisis management plan includes the a main plan containing, among others, characterization of hazard and evaluation of risk occurrence, including critical infrastructure, risk and hazard maps . Also, for the purpose of the National Emergency Management Plan, the ministers in charge of governmental departments, heads of central offices, and local governors write a special report on threats to national security, which includes an indication of the most important threats marked on the maps of risk [1].

It seems, therefore, that the development of quantitative methods for evaluation of risk damage to bridges will be useful in nature, because a valuable information posted on risk maps may be the result, which is a statutory requirement [1]. The tangible result of the research will be the guidelines for the assessment of damage risk to bridges in any given area of the country.

According to R. Grodzki [4], the taxonomy of threats in crisis management means assigning the risks to particular groups, which characterize a given hazard. However, from the point of view of crisis management, not all groups have the same priority. In analysis of threats we try to locate the source of threat in the first place, then the level of destruction, and its spatial extent as the last. In reference to the source of threat origin, the different groups can be attributed to specific natural, technical and anthropological threats [4]. The latter includes, among other issues, terrorism and military threats also considered by the authors in this paper-

It seems, therefore, that the continuation of the subject under consideration at the Academy is fully justified. The literature on the discussed issues is relatively poor, so additional studies should widen the perspective of the scientific community.

\section{THEORETICAL BACKGROUND OF AHP METHOD}

Analytical Hierarchy Process Method (AHP) was developed and described by T. L. Saaty, among many other papers, in [5], [6], [7]. A clear description of this method can be found in A. Ostręga [8], where she presents the theoretical basis of the method in practical engineering issues.

Among many advantages of the AHP, there are two most important ones. The first is presentation of the decision-making problem in the form of a hierarchical model, and the second is the simultaneous use of measurable and immeasurable factors [8]. 
In the AHP, normally used rating scales are not useful because they are based on pairwise comparison of each element to each other. For this purpose, a new 9-point scale was introduced [7], [9], [10]. Comparing the two elements together we determine which of these is important and to what extent but the value of 1 is attributed if both elements are equally important, and 9 if one element is much more important than the other [9].

When compared elements are not measurable, a linguistic approach is used, in such a case the linguistic variable takes as its values the verbal terms, also containing a 9-point scale of preferences [8].

In order to assess the elements on each level of a hierarchical structure, a comparison matrix is created (matrix $A$ ), where the level is equal to the number of items being compared [8].

Comparisons of main and sub-criteria, and those of the analyzed options by determining the degree of dominance of one over the other, are based on the experts' subjective opinions. Although the experts have the required knowledge in this matter they can also make mistakes in awarding ratings, resulting from the lack of consistency in the assessment [8].

Table 1

Values of random index ri. [8], [11]

\begin{tabular}{|c|c|c|c|c|c|c|c|c|c|c|c|c|c|c|c|}
\hline $\begin{array}{c}\text { Matrix } \\
\text { dimension }\end{array}$ & $\mathrm{n}$ & 1 & 2 & 3 & 4 & 5 & 6 & 7 & 8 & 9 & 10 & 11 & 12 & 13 & 14 \\
\hline $\begin{array}{c}\text { Random } \\
\text { index }\end{array}$ & r.i. & 0,00 & 0,00 & 0,58 & 0,90 & 1,12 & 1,24 & 1,32 & 1,41 & 1,45 & 1,49 & 1,51 & 1,54 & 1,56 & 1,57 \\
\hline
\end{tabular}

In the AHP method, the check of the results reliability is done by calculating the index of consistency i.c. and calculating the consistency ratio $c . r$. In order to eliminate any inconsistencies, the consistency ratio $c . r$. is calculated according to the formula (Eq. 2.1) $[8]$ :

$$
c . r .=\frac{i . c .}{r . i .} 100 \% \text {, }
$$

where r.i. is a random index depending on the level of matrix $n$, taking the values from 0 to 1.45 (Table 1), whereas the i.c. is the index of consistency determined from the dependency (Eq. 2.2) [8]:

$$
\text { i.c. }=\frac{\left(\lambda_{\max }-n\right)}{(n-1)},
$$

where $\lambda_{\max }$ is the maximum eigenvalue of matrix $A$, always greater or equal to the degree of the matrix $n$. 
The closer the value $\lambda_{\max }$ is to the level of matrix $n$, the more consistent are the comparisons. If the value of i.c. index does not exceed 0.1 , then it means that the experts are consistent in their evaluations [8].

According to G. Ginda [11], the approximate maximum eigenvalue of matrix $\lambda_{\max }$ can be calculated as the sum of the products averaged in a row of values of standardized weights and column sums corresponding to each criterion, which can be written as a formula (Eq. 2.3) [11]:

$$
\lambda_{\max }=\sum_{i=1}^{n}\left(w_{i} \sum_{j=1}^{n} a_{i j}\right) .
$$

where: $a_{i j}$ is an element of the analyzed matrix $A, w_{i}$ is the mean value of the $i$-th row of the matrix $A$.

A similar method of calculating the maximum eigenvalue of matrix $\lambda_{\max }$ was presented by K. Kastelik-Ginda [12] and K. Teknomo [13] in spreadsheets implementing of the AHP calculations.

AHP is based on a principle of logical consequence. The principle assures the appropriate consistency of input data. According to A. Ostręga [8], this principle has two important meanings. The first is related to the grouping of similar elements according to their homogeneity. The second one concerns the transitivity of ratings, i.e. the strength of the relationship between the compared elements. If the situation looks otherwise, it means that the assessment is inconsistent. Consequently, the value of c.r. rate should not reach $10 \%$. The higher value means that the reformulation of applied questions is needed while conducting pairwise comparisons [8].

It seems, therefore, that application of the AHP significantly facilitates making justified choices in multi-criteria optimization. Thus, solutions which are considerably better than the purely intuitive solutions are obtained.

\section{Method of eVAluation of DAMAge to BRIDGE CONSTRUCtions}

Work [14] presented semantic origins and basic concepts of risk analysis. As demonstrated, the concept of risk is understood and defined in various ways. However, it seems that the most well-known equation which allows to determine the risk of damage to the bridge structure is expressed by formula (Eq. 3.1) [14]:

$$
R=p \times c
$$

where $p$ is the probability of a terrorist attack on a bridge, and $c$ is a consequence of the destruction (damage). 
In case of bridges, the consequence of their damage is very dangerous. The extent of the consequences is influenced, among other issues, by traffic volume (road class), length of span, height of support systems, and materials used for their construction.

The paper omitted discussion over evaluation of the consequences of bridge destruction, concentrating mainly on the likelihood of a damage.

By determination of probability of damage to the bridge structure it was assumed that it is the value defining our expectations in reference to the possibility of occurrence of a given event, in this case - a terrorist attack. This figure is therefore used to determine the possibility of a "random event" and has a value in the range $<0 ; 1>$, whereas the sum of these numbers (that is, the total value for all the analyzed bridges) is always equal to unity. Since the determination of the probability basing only on subjective grounds and feelings may be unsuitable for engineering practice, it was therefore necessary to establish the method of precise determination of the likelihood of that kind.

Given the assumption that the sum of the probability $p$ of bridges destruction in given area must be equal to unity, i.e. there is only one bridge that will be destroyed, it is always easier to compare only two options with each other, especially when the hierarchy is expressed in linguistic variables. In order to determine the value of the probability, the AHP method was used.

It was assumed that the probability of damage to the bridge structure is equal to the coefficient of the option achieved with the AHP method, the options here are all the bridges situated in the given location.

In the analysis of the possibility of a terrorist attack on the bridges it was found out that the criteria for assessing the likelihood of damage to such facilities is original (primary) location of the property and the possibility of destruction (damage) of supporting structures.

In the case of a bridge location, such aspects as the ability to protect and defend the construction must be taken into consideration. These aspects are usually associated with a distance from the city center (criterion K1), and the volume of traffic on the bridge (criterion K2), which is directly related to the road class. It can be assumed that objects further away from the city center are not monitored or protected, and therefore the probability associated with the earlier placing mines on the bridge will be higher. With regard to the volume of traffic, it is clear that the terrorist attack on a bridge is associated with paralysis of transportation in the adjacent area of the country, it seems therefore that bridges with significant traffic should be an interesting and important target for potential terrorists.

Details on the construction of bridge structure should be viewed in several ways, including, among many other issues, construction of not only supports but also spans, and the type of material of which they are made.

According to the instruction [15], bridges may be destroyed mainly in a partial way, which relies on the selection of those parts of the structure whose damage would prevent restoration of operability of these constructions by placing the accompanying 
bridge spans, with which the army is equipped. As the optimal solution to the partial destruction of bridges and overpasses, the damage to spans of the length of more than $25 \mathrm{~m}$, which are located across the river can be considered, while avoiding the need for destruction of intermediate supports.

While analyzing the bridge structure in terms of its effortless damage, the type of spans structure is to be determined, because explosive materials (EM) should be placed on the load-bearing elements. Although this is not a necessary requirement, the application of EM should be located on places where the greatest bending moments occur (and thus the stress) in the construction of the span. Considering the principle of the minimum number of loads, it is necessary to establish destructible sections in places where there is the smaller amount of elements to break in the cross section of the span [15].

According to the instruction [15], in the case of bridges with spans longer than $30 \mathrm{~m}$, it is sufficient to destroy only spans, otherwise it is necessary to destroy both the spans and indirect support (criterion K3).

As it regards the material with which bridges are made (criterion K4) it was found out that it is usually easier to destroy bridges made of: wood, stone, concrete, reinforced concrete, and steel on the last place. This was due to the fact that steel bridges have usually a lot more load-bearing structural elements than majority of massive concrete or reinforced concrete bridges. Steel is also a more plastic material, so in case of similar cracks steel behaves safer than brittle materials, such as concrete.

As to the construction of bridge, it should be noted that usually the cable-stayed and suspended bridges are most vulnerable to terrorist attacks, then truss and beam bridges (with a small number of beams), and at the end - arc and plate ones (criterion K5).

It also turns out that the height of the spans above water or land is of much significance (criterion K6) because it directly affects the ability of placing mines on the spans from the bottom, which is recommended for most structures (e.g. in case of beam and plate bridges) due to location of tensile elements.

4. EXAMPLE OF DETERMINING THE PROBABILITY OF DAMAGE TO THE BRIDGE STRUCTURE IN CONNECTION WITH TERRORIST ATTACKS

The authors analyzed six selected bridges located in the city of Wroclaw area (Table 2 [16] and Figure 1 [16]). Certain bridges were characterized by both varied structure, and location.

Table 3 shows the weights of the criteria adopted for the analysis. Subjective assessment expressed as the priority value shows that the traffic flow (K2) and the construction of the span (K5) has the greatest impact on the safety of the structure. 
Table 2

Data concerning selected bridges adopted for the analysis [16]

\begin{tabular}{|c|c|c|c|c|c|c|c|}
\hline Variant & \multirow{2}{*}{ Bridge name } & $\begin{array}{c}\text { Bridge } \\
\text { protection }\end{array}$ & $\begin{array}{c}\text { Traffic } \\
\text { volume }\end{array}$ & $\begin{array}{c}\text { Length of the } \\
\text { analyzed span }\end{array}$ & $\begin{array}{c}\text { Con- } \\
\text { struction } \\
\text { material }\end{array}$ & $\begin{array}{c}\text { Spans } \\
\text { construction }\end{array}$ & $\begin{array}{c}\text { Access to } \\
\text { the span } \\
\text { bottom }\end{array}$ \\
\cline { 3 - 8 } & K1 & K2 & K3 & K4 & K5 & K6 \\
\hline 2 & $\begin{array}{c}\text { Bolesław } \\
\text { Krzywousty }\end{array}$ & Poor & Low & $3 \times 25+48$ & $\begin{array}{c}\text { Reinforced } \\
\text { concrete }\end{array}$ & Arch & Very good \\
\hline 3 & $\begin{array}{c}\text { Władysław } \\
\text { Sikorski }\end{array}$ & Good & Heavy & $2 \times 46,5$ & $\begin{array}{c}\text { Reinforced } \\
\text { concrete } \\
\text { Steel }\end{array}$ & Beam & Very good \\
\hline 4 & Polanowicki & Poor & Very low & ok. $30 \mathrm{~m}$ & Steel & Beam & Good \\
\hline 5 & Grunwaldzki & Very good & $\begin{array}{c}\text { Very } \\
\text { heavy }\end{array}$ & 112,5 & Steel & Suspension & Poor \\
\hline 6 & Milenijny & Very good & $\begin{array}{c}\text { Very } \\
\text { heavy }\end{array}$ & $68+153+68$ & $\begin{array}{c}\text { Reinforced } \\
\text { concrete } \\
+ \text { Steel } \\
\text { strings }\end{array}$ & Cable-stayed & Good \\
\hline
\end{tabular}

Table 3

Criteria weights adopted for analysis

\begin{tabular}{|c|c|c|c|c|c|c|c|c|}
\hline \multicolumn{2}{|c|}{ Specification } & K1 & K2 & K3 & K4 & K5 & K6 & Priority \\
\hline Bridge protection & $\mathrm{K} 1$ & 1,00 & 0,60 & 0,80 & 5,00 & 0,80 & 6,0 & 0,201 \\
\hline Traffic volume & $\mathrm{K} 2$ & 1,67 & 1,00 & 1,00 & 6,00 & 0,80 & 5,00 & 0,246 \\
\hline Spans length & $\mathrm{K} 3$ & 1,25 & 1,00 & 1,00 & 3,00 & 0,90 & 5,00 & 0,212 \\
\hline Construction material & $\mathrm{K} 4$ & 0,20 & 0,17 & 0,33 & 1,00 & 0,25 & 2,00 & 0,058 \\
\hline Span construction & $\mathrm{K} 5$ & 1,25 & 1,25 & 1,11 & 4,00 & 1,00 & 6,00 & 0,245 \\
\hline Access to the span bottom & $\mathrm{K} 6$ & 0,17 & 0,20 & 0,20 & 0,50 & 0,17 & 1,00 & 0,038 \\
\hline \multicolumn{7}{|c|}{ Index of consistency i.c. $=0,03$ Consistency ratio $c . r .=2,20 \%$} \\
\hline
\end{tabular}


a)
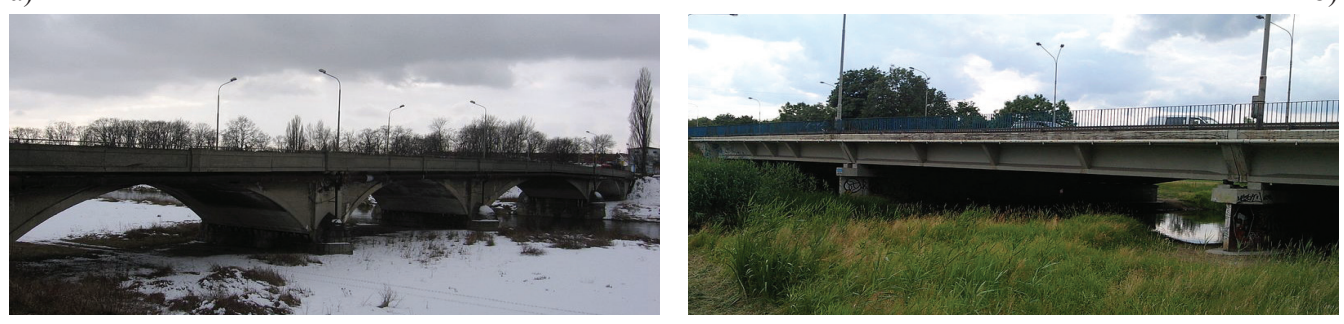

c)
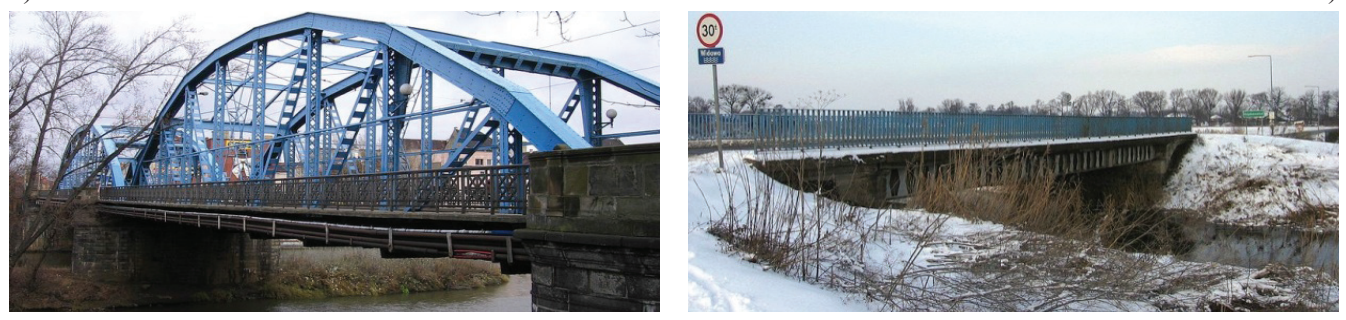

e)

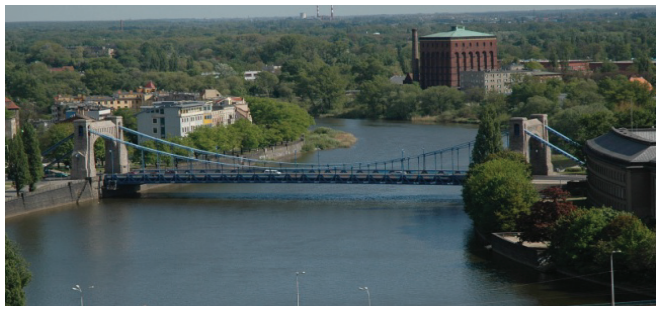

Fig. 1. View of the bridges [16]: a) Bolesław Chrobry (Swojczycki), b) Bolesław Krzywousty, c) Władysława Sikorski, d) Polanowicki, e) Grunwaldzki, f) Milenijny [16]

Table 4

Evaluation of bridges according to criterion 1 - Bridge protection (K1)

\begin{tabular}{|c|c|c|c|c|c|c|c|c|}
\hline \multicolumn{2}{|c|}{ Specification } & W1 & W2 & W3 & W4 & W5 & W6 & Priority \\
\hline Bolesława Chrobrego & W1 & 1,00 & 4,00 & 4,00 & 1,00 & 8,00 & 8,00 & 0,366 \\
\hline Bolesława Krzywoustego & W2 & 0,25 & 1,00 & 1,00 & 0,40 & 4,00 & 4,00 & 0,125 \\
\hline Władysława Sikorskiego & W3 & 0,25 & 1,00 & 1,00 & 0,40 & 4,00 & 4,00 & 0,125 \\
\hline Polanowicki & W4 & 1,00 & 2,50 & 2,50 & 1,00 & 8,00 & 8,00 & 0,310 \\
\hline Grunwaldzki & W5 & 0,13 & 0,25 & 0,25 & 0,13 & 1,00 & 1,00 & 0,036 \\
\hline Milenijny & W6 & 0,13 & 0,25 & 0,25 & 0,13 & 1,00 & 1,00 & 0,036 \\
\hline \multicolumn{7}{|c|}{ Index of consistency i.c. $=0,02$ Consistency ratio c.r. $=1,71 \%$} \\
\hline
\end{tabular}


Tables 4-9 show the evaluations of the various options (types of bridges) with reference to six adopted criteria (K1-K6). Values of priorities for the options are also given.

Table 5

Evaluation of bridges according to criterion 2 - Traffic volume (K2)

\begin{tabular}{|c|c|c|c|c|c|c|c|c|}
\hline \multicolumn{2}{|c|}{ Specification } & W1 & W2 & W3 & W4 & W5 & W6 & Priority \\
\hline Bolesław Chrobry & W1 & 1,00 & 0,10 & 0,50 & 2,00 & 0,20 & 0,10 & 0,042 \\
\hline Bolesław Krzywousty & W2 & 10,00 & 1,00 & 3,00 & 9,00 & 2,00 & 1,00 & 0,327 \\
\hline Władysław Sikorski & W3 & 2,00 & 0,33 & 1,00 & 6,00 & 0,70 & 0,60 & 0,128 \\
\hline Polanowicki & W4 & 0,50 & 0,11 & 0,17 & 1,00 & 0,10 & 0,10 & 0,025 \\
\hline Grunwaldzki & W5 & 5,00 & 0,50 & 1,43 & 10,00 & 1,00 & 0,90 & 0,204 \\
\hline Milenijny & W6 & 10,00 & 1,00 & 1,67 & 10,00 & 1,11 & 1,00 & 0,274 \\
\hline \multicolumn{7}{|l}{ Index of consistency $i . c .=0,04$ Consistency ratio c.r. $=2,88 \%$} \\
\hline
\end{tabular}

Table 6

Evaluation of bridges according to criterion 3 - Span length (K3)

\begin{tabular}{|c|c|c|c|c|c|c|c|c|}
\hline \multicolumn{2}{|c|}{ Specification } & W1 & W2 & W3 & W4 & W5 & W6 & Priority \\
\hline Bolesław Chrobry & W1 & 1,00 & 1,50 & 0,40 & 0,60 & 0,20 & 0,10 & 0,053 \\
\hline Bolesław Krzywousty & W2 & 0,67 & 1,00 & 0,30 & 0,50 & 0,15 & 0,09 & 0,040 \\
\hline Władysław Sikorski & W3 & 2,50 & 3,33 & 1,00 & 3,00 & 0,70 & 0,50 & 0,174 \\
\hline Polanowicki & W4 & 1,67 & 2,00 & 0,33 & 1,00 & 0,40 & 0,20 & 0,080 \\
\hline Grunwaldzki & W5 & 5,00 & 6,67 & 1,43 & 2,50 & 1,00 & 0,80 & 0,255 \\
\hline Milenijny & W6 & 10,00 & 11,11 & 2,00 & 5,00 & 1,25 & 1,00 & 0,398 \\
\hline \multicolumn{7}{|c|}{ Index of consistency i.c. $=0,02$ Consistency ratio c.r. = 1,68\% } \\
\hline
\end{tabular}

Table 7

Evaluation of bridges according to criterion 4 - Construction material (K4)

\begin{tabular}{|c|c|c|c|c|c|c|c|c|}
\hline \multicolumn{2}{|c|}{ Specification } & W1 & W2 & W3 & W4 & W5 & W6 & Priority \\
\hline Bolesław Chrobry & W1 & 1,00 & 1,00 & 4,00 & 4,00 & 4,00 & 4,00 & 0,334 \\
\hline Bolesław Krzywousty & W2 & 1,00 & 1,00 & 4,00 & 4,00 & 4,00 & 4,00 & 0,334 \\
\hline Władysław Sikorski & W3 & 0,25 & 0,25 & 1,00 & 1,00 & 1,00 & 1,00 & 0,083 \\
\hline Polanowicki & W4 & 0,25 & 0,25 & 1,00 & 1,00 & 1,00 & 1,00 & 0,083 \\
\hline Grunwaldzki & W5 & 0,25 & 0,25 & 1,00 & 1,00 & 1,00 & 1,00 & 0,083 \\
\hline Milenijny & W6 & 0,25 & 0,25 & 1,00 & 1,00 & 1,00 & 1,00 & 0,083 \\
\hline
\end{tabular}


Analyzing the consistency ratio c.r. of values showed in the tables 4-9 it can be concluded that the evaluation of different solutions are very consistent since the value of c.r. was much less than $10 \%$.

Table 8

Evaluation of bridges according to criterion 5 - Span construction (K5)

\begin{tabular}{|c|c|c|c|c|c|c|c|c|}
\hline \multicolumn{2}{|c|}{ Specification } & W1 & W2 & W3 & W4 & W5 & W6 & Priority \\
\hline Bolesław Chrobry & W1 & 1,00 & 0,80 & 0,60 & 0,80 & 0,40 & 0,20 & 0,081 \\
\hline Bolesław Krzywousty & W2 & 1,25 & 1,00 & 0,80 & 1,00 & 0,60 & 0,40 & 0,115 \\
\hline Władysław Sikorski & W3 & 1,67 & 1,25 & 1,00 & 1,40 & 0,80 & 0,40 & 0,144 \\
\hline Polanowicki & W4 & 1,25 & 1,00 & 0,71 & 1,00 & 0,40 & 0,20 & 0,094 \\
\hline Grunwaldzki & W5 & 2,50 & 1,67 & 1,25 & 2,50 & 1,00 & 0,80 & 0,215 \\
\hline Milenijny & W6 & 5,00 & 2,50 & 2,50 & 5,00 & 1,25 & 1,00 & 0,351 \\
\hline \multicolumn{7}{|c|}{ Index of consistency i.c. $=0,02$ Consistency ratio c.r. $=1,22 \%$} \\
\hline
\end{tabular}

Table 9

Evaluation of bridges according to criterion 6 - access to span bottom (K6)

\begin{tabular}{|c|c|c|c|c|c|c|c|c|}
\hline \multicolumn{2}{|c|}{ Specification } & W1 & W2 & W3 & W4 & W5 & W6 & Priority \\
\hline Bolesław Chrobry & W1 & 1,00 & 1,00 & 8,00 & 4,00 & 8,00 & 4,00 & 0,351 \\
\hline Bolesław Krzywousty & W2 & 1,00 & 1,00 & 8,00 & 4,00 & 8,00 & 4,00 & 0,351 \\
\hline Władysław Sikorski & W3 & 0,13 & 0,13 & 1,00 & 0,25 & 1,00 & 0,25 & 0,036 \\
\hline Polanowicki & W4 & 0,25 & 0,25 & 4,00 & 1,00 & 4,00 & 1,00 & 0,113 \\
\hline Grunwaldzki & W5 & 0,13 & 0,13 & 1,00 & 0,25 & 1,00 & 0,25 & 0,036 \\
\hline Milenijny & W6 & 0,25 & 0,25 & 4,00 & 1,00 & 4,00 & 1,00 & 0,113 \\
\hline \multicolumn{7}{|c|}{ Index of consistency $i . c .=0,04$ Consistency ratio c.r. $=2,84 \%$} \\
\hline
\end{tabular}

Table 10

Final AHP priorities for bridges

\begin{tabular}{|c|c|c|}
\hline LP. & Bridge name & AHP priority \\
\hline 1. & Bolesław Chrobry & 0,1476 \\
\hline 2. & Bolesław Krzywousty & 0,1751 \\
\hline 3. & Władysław Sikorski & 0,1349 \\
\hline 4. & Polanowicki & 0,1177 \\
\hline 5. & Grunwaldzki & 0,1704 \\
\hline 6. & Milenijny & 0,2543 \\
\hline
\end{tabular}


Table 10 and Figure 2 present the final results of the calculations. The calculations clearly show that the Millenijny Bridge (W6) is the most vulnerable to terrorist attacks, next the Boleslaw Krzywousty Bridge (W2), and the Grunwaldzki Bridge (W5). Undeniably, such conclusions can be also drawn in an intuitive way, but by using the AHP method numerical values that can be used for further analysis are obtained.

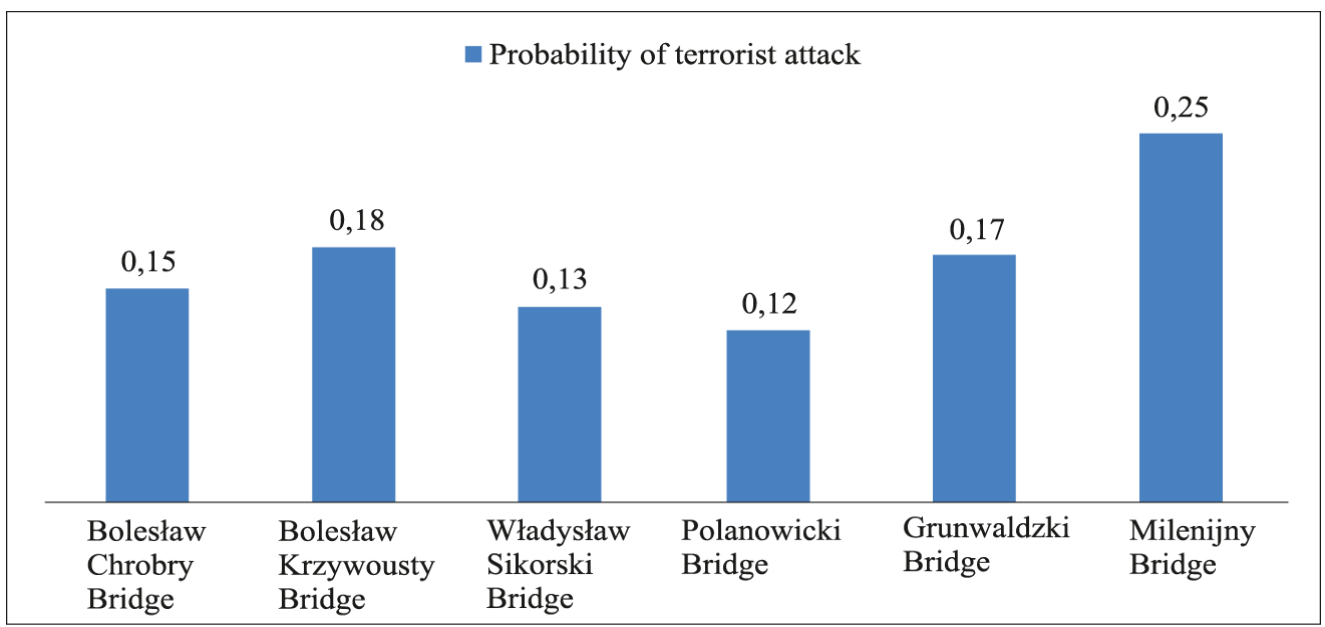

Fig. 2. Probability of terrorist attack on chosen bridges

\section{Summary}

Application of AHP method to evaluate the probability of a terrorist attack would certainly not exclude any subjective assessments of experts. However, it facilitates the assessment process to a great extent, because it requires direct comparison of two options at a time only. It is worth noting that several evaluation criteria are expressed in the linguistic form. Possibility of application of other multi-criteria methods of optimization is therefore quite limited. Throughout the decision-making process, experts' choices are constantly modified with the values given by coefficients i.c. and c.r. But the most important advantage of the presented approach consists in a possibility of easy and rational explanation of the taken decisions (accepted rankings of considered alternatives) instead of an explanation based on personal knowledge, experience, feelings, and intuition only.

The example presented in the paper was expected to show the applicability of the AHP method to solve that problem. The accuracy (objectivity) of the analyses depends on the quantity and "quality" of the adopted criteria which depends only on the knowledge of a person who carries out the study. Bridges are of very different structures (almost unique), thus adopting all the criteria, is virtually impossible. It is also clear that 
considering too many criteria can strongly impede conducting of such analyses and can lead to narrow a choice of required knowledge sources to a small group of experts only. It would in turn limit access to needed knowledge especially in the smaller towns and peripheral areas of particular regions.

It also seems reasonable to develop guidelines for conducting these analyses at the appropriate organizational level.

The evaluation of probability of bridge damage as a result of terrorist attacks based on AHP utilisation is also applicable for solution of decision making problems in other construction engineering areas [17], [18] and in the field of construction logistics [19].

The presented results carried out under the theme "Method of assessing risk of damage to bridges in terms of potential terrorist attacks" were financed from own resources of General Kościuszko Military Academy of Land Forces.

\section{REFERENCES}

1. Bill of April 26, 2007 on crisis management, (Dz.U. 2007 nr 89 poz. 590), [in Polish].

2. D. Pyza, Transport system and its model within the logistic system in Poland, Scientific papers of the Warsaw University of Technology, z. 76, Transport, 2010, [online: 20.03.2012r.] www.it.pw.edu.pl/ prace-naukowe/z76/pyza.pdf, [in Polish].

3. A. Kogut, http://mfiles.pl/pl/index.php/Transport infrastructure. [online: 20.03.2012r.], [in Polish].

4. R. Grodzki, Crisis management, good practices, Wydawnictwo DIFIN S.A., Warszawa, 2012, [in Polish].

5. T. L. Saaty, The Analytical Hierarchy Process, RWS Publications, Pittsburgh, PA, 1990.

6. T. L. Saaty, L. Vargas, Models, Methods, Concepts and Applications of the Analytic Hierarchy Process. Boston, Kluwer Academic Publishing, 2001.

7. T. L. Saaty, Deriving the AHP 1-9 Scale from First Principles. ISAHP 2001, Berne - Switzerland, 2001.

8. A. Ostręga, Ways of utilization of pits and areas after mining exploitation of carbonite raw materials, on the example of Krzemionki Podgórskie in Kraków. Doctor theses. Akademia Górniczo-Hutnicza, Wydział Górnictwa i Geoinżynierii, Kraków, 2004, [in Polish].

9. W. Przybyło, S. Krężołek, Application of the AHP in building, [online: 10.02.2009 r.] (in Polish] www. fema.pl/ mit/PUBLIKACJE_WLASNE/doc/ahpwbsk-olsztyn.doc.

10. M. Dytczak, The selected methods of solving the multictiterion decision problems in building, Politechnika Opolska, Opole, 2010 [in Polish].

11. G. Ginda, Forecasting based on multiatribute analysis. Forecasting and simulations. Politechnika Opolska, 2007, [online: 08.04.2012r.] http://www.bopis.po.opole.pl/pis06_win.pdf [in Polish].

12. K. Kastelik-Ginda, Application of the AHP method for the end-of-year high school classification, [online: 06.04.2012r.] www.kkastelik.scholaris.pl, [in Polish].

13. K. Teknomo, Analytic Hierarchy Process, Kardi Teknomo's Homepage, [online: 06.04.2012r.] http:// people.revoledu.com/kardi/tutorial/AHP/AHP.htm.

14. D. Skorupka, The method of identification and assessement of risk of construction enterprise, Wojskowa Akademia Techniczna, Warszawa, 2007, [in Polish].

15. Saper works and distructions, Sztab Generalny WP, Szefostwo Wojsk Inżynieryjnych, Syg. Inż. 572/94, Warszawa, 1995, [in Polish]. 
16. http://pl.wikipedia.org/wiki/Kategoria:Mosty_Wroc\%C5\%82awia, [online: 06.04.2012r.].

17. O. Kapliński, Methods and models of research in building engineering, Wydawnictwo PAN KILiW IPPT, Warszawa, 2007 [in Polish\}.

18. T. Kasprowicz, Building enterprises engineering, ITE Radom, Warszawa-Radom, 2002, [in Polish].

19. A. Sobotka, Logistics of building enterprises, Wydawnictwo AGH, Kraków, 2010, [in Polish].

Received 15.01.2013

Revised 04.04.2013 